
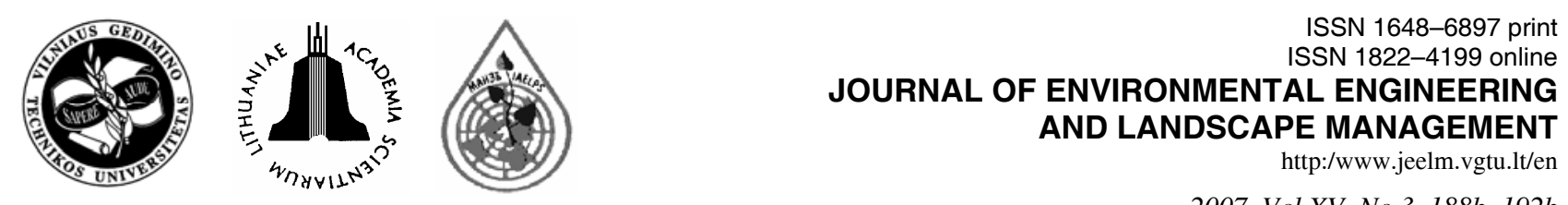

2007, Vol XV, No 3, 188b-192b

\title{
Paper revien \\ PREVENTIVE MAINTENANCE OF FLEXIBLE PAVEMENT AND MECHANICAL PROPERTIES OF STEEL SLAG ASPHALT
}

\author{
Hassan Ziari ${ }^{1}$, Mohammad M. Khabiri ${ }^{2}$ \\ ${ }^{1}$ Dept of Civil Engineering, Iran University of Science and Technology, \\ ${ }^{2}$ Khabiri@iust.ac.ir
}

Submitted 6 Feb 2007; accepted 28 May 2007

\begin{abstract}
Preventive maintenance is beneficial if pavement life is increased while maintaining its service ability, and it is an environmental problem. Steel slag material is inorganic, it can neither be incinerated nor decomposed, so it may be difficult to reclaim. This work aims to study the performance of asphalt concrete where some of the fractional fine aggregate is replaced with crushed steel slag material. Steel slag materials are brittle and rich in carbon and silicon, so the key technical indexes of steel slag-asphalt concrete are strength. Materials used in the tests included AC 60-70 bitumen, limestone aggregate and crushed recycled steel slag. The Marshall test was used to examine the influence of optimal asphalt content, volume properties and strength of asphalt concrete when different percentages of crushed steel slag were added. The high-temperature stability and creep stiffness performance of steel slag asphalt concrete was also tested, and the results are satisfactory. The investigation has demonstrated that the recycling and use of waste steel slag in asphalt concrete is feasible.
\end{abstract}

Keywords: steel slag, asphalt concrete, creep stiffness, waste material, preventive maintenance, recycled.

\section{Introduction}

With rapid development of steel industry in Iran, the amount of steel slag sharply increases. Steel slag is a byproduct from the steel-making process, the majority of which ends up in deposits and thus gradually becomes an environmental problem, so the availability of ways to handle steel slag is getting more important. On the other hand, in Iran, and in most industrialized countries, there is a great demand for aggregate mainly in civil engineering industry, especially in the field of road construction. The last statement holds us responsible to save natural resources by using industrial byproducts and to increase their utilization rate wherever their technical properties are suitable concerning the relevant application field.

The demand for natural aggregate resources such as basalt, gravel, limestone and other processed rocks either brings about environmental problems or makes cost of projects increase sharply because of lack of such aggregates. This paper intends to report the characteristics and properties of steel slag as road construction aggregate, besides the asphalt pavement performance, hence, evaluate the feasibility of steel slag used as aggregate in asphalt mixture and pavement construction field of application.

The initial applications of steel slag asphalt took place in late 1960s when the United States and Canada constructed test roads with steel slag asphalt to testify the stability of pavements [1]. From middle 1970s to middle 1980s, Baltimore city (Maryland, United States) paved many sidewalks with steel slag asphalt [2]. From 1990 to
1995, the total amount of steel slag asphalt application reached about 250 thousand tons in New York [3].

It is reported that steel slag has been produced and used successfully in different European countries as a road construction material because of their advantageous technical properties. Thus steel slag was used not only for unbound layers like road bases and sub-bases, but also for bituminous bound layers like surface layers [4].

\section{Preventive maintenance treatment}

Various preventive maintenance treatments are employed by highway agencies to restore pavement condition and retard future deterioration. For specific climate conditions and traffic levels, the performance of the restored pavement will depend not only on the type of maintenance treatment, but also on the existing pavement condition when these treatments are applied. Crack sealing is the placement of specialized materials into working cracks by the cut and seal method. This method consists of cutting the desired reservoir shape at the working crack in the existing asphalt surface, cleaning the cut surfaces and placing the specified materials into the cavity. The cutting is performed with either a random crack saw or a crack router. This treatment is usually performed on working cracks and sometimes done in conjunction with an asphalt crack filling treatment for non-working cracks. Sealing cracks and open construction joints in the flexible pavement surface is done to prevent water from entering the pavement structure. 
The existing pavement should be relatively new with a good base and cross section. On a flexible base, the HMA surface should be two to four years old and on a composite pavement (with underlying concrete), one to two years old. The visible surface distress may include: fairly straight open longitudinal and transverse cracks with slight secondary cracking and slight raveling at the crack face, and no patching or very few patches in excellent condition.

Sealing cracks in pavements with an asphalt surface is a preventive maintenance activity performed by most highway agencies. A number of materials and methods are in use within Iran for this purpose.

Crack sealing can have many benefits, including substantial life cycle cost savings, improved customer service, and better system wide performance. Crack sealing may also affect the pavement in many ways such as tracking of sealing material by tire action, reduced skid resistance, and a rougher pavement. Crack sealing is beneficial if pavement life is increased while maintaining serviceability. The primary concern is to invest gate and document the effectiveness of crack sealing with respect to:

1. economic benefits,

2. maintaining and/or improving serviceability, and

3. extending pavement life.

A three-layer with a crack sealing point mode was developed to investigate the mechanical and material properties of flexible pavement. This model is provided by SAP program. For modeling the elastic linear behavior granular base, asphalt layer and crack sealing, SAP provided excellent opportunities.

\section{General characteristics and properties of steel slag}

\subsection{Technical properties}

As it is known, only high-quality aggregate can be used in hot-mix asphalt (HMA) mixtures. Therefore, the technical properties of processed aggregates which are used for these constructions are of fundamental importance. The most important properties and test results are shown in Table 1.
Table 1. Technical properties of steel slag and natural aggregates

\begin{tabular}{l|c|c}
\hline \multicolumn{1}{c|}{ Characteristies } & Steel Slag & Limestone \\
\hline Density, $\mathrm{g} / \mathrm{cm}^{3}$ & 3,30 & 2,73 \\
\hline Loose bulk density, g/cm ${ }^{3}$ & 1,90 & 1,45 \\
\hline L. A. abrasion, \% & 13,2 & 23,0 \\
\hline Crushing value, \% & 12,1 & 15,6 \\
\hline Water absorption, \% & 1,29 & 1,08 \\
\hline
\end{tabular}

According to Table 1, steel slag can be processed and used as aggregate of high quality which is comparable with natural aggregates. The high bulk density qualifies steel slag used as construction materials. The loose bulk density of steel slag is $1,9 \mathrm{ton} / \mathrm{m}^{3}$ which is higher than that of natural aggregates. The two indexes of density guarantee good crushing resistance and abrasion resistance performances of steel slag by L. A. abrasion and crushing tests.

These are two very important indexes of road construction aggregate because of rolling and contacting when paving asphalt road. The above index of density indicates the cube shape of a slag particle and lower flat, and the highest value also guarantees the internal friction angle.

This is more important for aggregate used in HMA because of stone on stone contact requirement [5]. All the other technical properties listed in Table 1 are comparable or even better than those of natural aggregates. In particular the high level of strength described by the impact and crushing value and additionally the rough, surface texture are predominant.

Successful use in hydraulic engineering and backfilled ground base materials confirm these good technical properties of steel slag and guarantees to be used in asphalt layer against rut, deformation and polishing.

The waste broken steel slag used in the study is from Isfahan steel plant. The maximum steel slag particle size is $4,75 \mathrm{~mm}$ and is adaptive to No 4 type gradation [6]. Fig 1 shows the gradation curve of the broken steel slag particles.

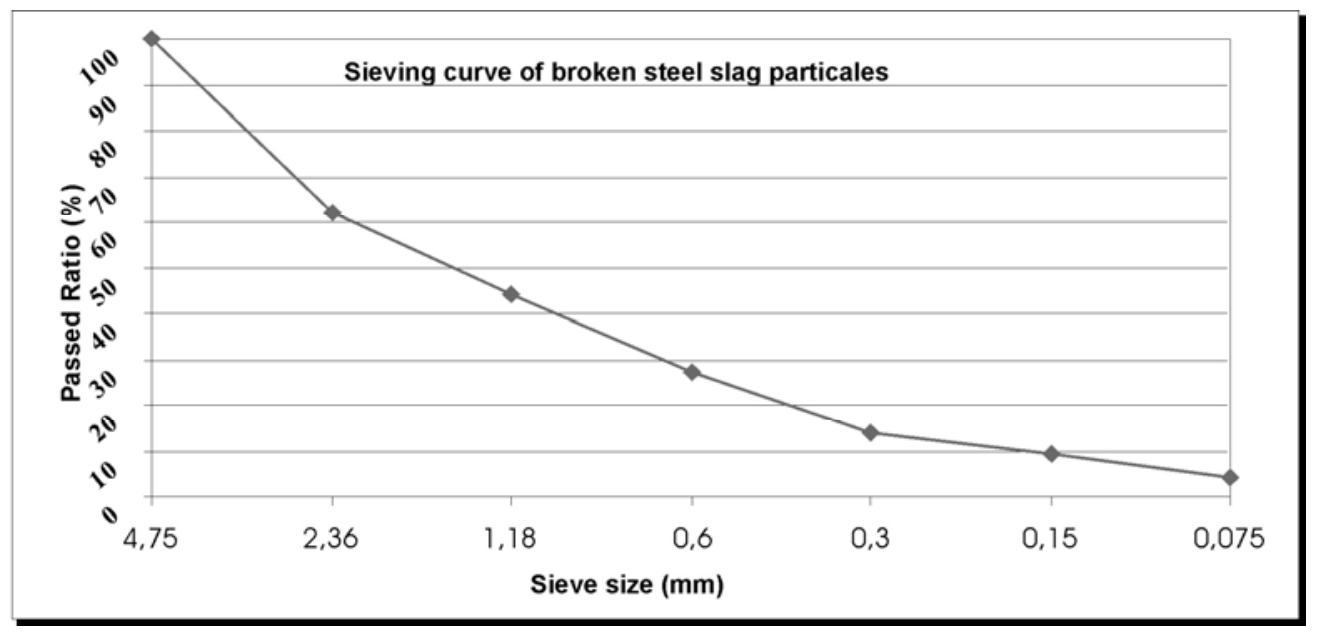

Fig 1. Sieving curve of broken steel slag particles 


\subsection{Bitumen}

Bitumen is the most commonly used material in pavement construction today because of its high engineering performance capabilities such as elasticity, adhesion and water resistance. Bitumen is known to be a complicated colloidal system of hydrocarbon materials which are composed of asphaltenes, resins and oils. Today's bitumen is produced mainly by refining crude oil, and its physical and chemical properties can be altered or improved by blending, air blowing, additives, etc. The interface between the bitumen and aggregate has been much focused in order to determine the chemical factors that influence bonding between the two materials.

AC $60-70$ bitumen from Tehran Bitumen Factory is used in the study, the relative performance indexes were tested according to "Standard Test Methods of Bitumen and Bituminous Mixtures for Highway Engineering" (ASTM D-83) and are listed below:

- penetration $\left(25^{\circ} \mathrm{C}, 100 \mathrm{~g}, 5 \mathrm{~s}, 0,1 \mathrm{~mm}\right)-63,4$;

- softening point $\left({ }^{\circ} \mathrm{C}\right)-46$;

- ductility $\left(15^{\circ} \mathrm{C}, \mathrm{cm}\right)-120 \mathrm{~cm}$;

- flash point $-287^{\circ} \mathrm{C}$;

- density $\left(25^{\circ} \mathrm{C}\right)-1,028 \mathrm{~g} / \mathrm{cm}^{3}$;

- weight loss $-0,03 \%$.

\subsection{Mineral aggregate}

The physical and chemical properties have an intense effect on asphalt mixtures because of the effect of aggregate properties on the adhesive bond between asphalt and aggregate. Many factors have an influence on bonding, such as size and shape of aggregate, pore volume and size, surface area, chemical constituents at the surface, acidity and alkalinity, adsorption size surface density, and surface charge or polarity. The mineral aggregate used in the study is limestone.

\section{Test projects}

A test program was set up to determine the optimal dosage of waste broken steel slag particles. A maximum steel slag particle size of $4,75 \mathrm{~mm}$ and four steel slag contents were chosen: $0,5,10,15$ and $20 \%$ in terms of the total aggregate weight [7]. A suspending and closegrained gradation of Iranian flexible pavement Code No 4 was used as showed in Fig 2. These curves were similar for all the steel slag dosages.

The investigation was conducted with Marshall specimens (diameter of $10 \mathrm{~cm}$, height of $6,35 \mathrm{~cm}$ ). To enable comparison, the same binder content of 3,8\% is used for all the different mixtures. The additive of hydrated lime (as a filler) was used to improve the resistance to water damage of the asphalt mixtures.

The following properties were tested in the study:

- strength and volume properties - Marshall test;

- stability - creep stiffness test.

\section{Results and discussion}

\subsection{Marshall test}

The Marshall test results of mixtures with different steel slag replacement are shown in Table 1. The apparent specific gravity of steel slag is $3,30 \mathrm{~g} / \mathrm{cm}^{3}$ and $2,73 \mathrm{~g} / \mathrm{cm}^{3}$ for limestone aggregate.

From Table 2, the maximal theoretical densities of mixtures increase evidently with the increase of steel slag replacement ratio, but the air void ratios of the Marshall specimens have a relatively lower increase. Fig 3 shows that the strength indexes of Marshall stability and creep stiffness are decreasing substantially with the increase of steel slag replacement.

\subsection{Stability test}

The creep stiffness test intended to test the dynamic stability and evaluate the high temperature stability of mixtures. According to regulations ASTM D4123-82, Marshal specimens were prepared and laid down for $24 \mathrm{~h}$, then tested according to the regulation ASTM D4123-82 (temperature $60{ }^{\circ} \mathrm{C}$, load $2.5 \mathrm{KN}$, frequency $1 \mathrm{HZ}$ ) [8]. For this test, Universal Testing Machine (UTM-5) was used [7].The results are showed in Table 2.

We can conclude that the dynamic high-temperature stability descends with increasing steel slag replacement. No internal rushed steel slag particles could be observed when the samples were broken off with fingers and the thumb after the test [6].

\section{Conclusions}

Up to now, in Iran, there have been few special investigations on the application of waste steel slag in the field of pavement, not to mention field applications.

This work is, therefore, the first to thoroughly test the properties of steel slag as asphalt mixture aggregate for expressway construction.

The authors are aware that this work is just leading a way to treat and utilize steel slag, and that further study, more practice and adequate tests will be needed. The following could be summarized as conclusions of this work.

Table 2. Marshall test results for different steel slag replacement

\begin{tabular}{c|c|c|c|c}
\hline $\begin{array}{c}\text { Amount of steel slag } \\
\text { added \% }\end{array}$ & $\begin{array}{c}\text { Maximal theory density, } \\
\mathrm{g} / \mathrm{cm}^{3}\end{array}$ & Air void ratio, \% & Marshall stability, KN & Creep stiffness, Mpa \\
\hline 0 & 2,53 & 4,13 & 13,76 & 410 \\
\hline 5 & 2,521 & 4,19 & 13,32 & 386 \\
\hline 10 & 2,514 & 4,16 & 12,72 & 302 \\
\hline 15 & 2,503 & 4,22 & 11,69 & 275 \\
\hline 20 & 2,496 & 4,25 & 11,13 & 233 \\
\hline
\end{tabular}




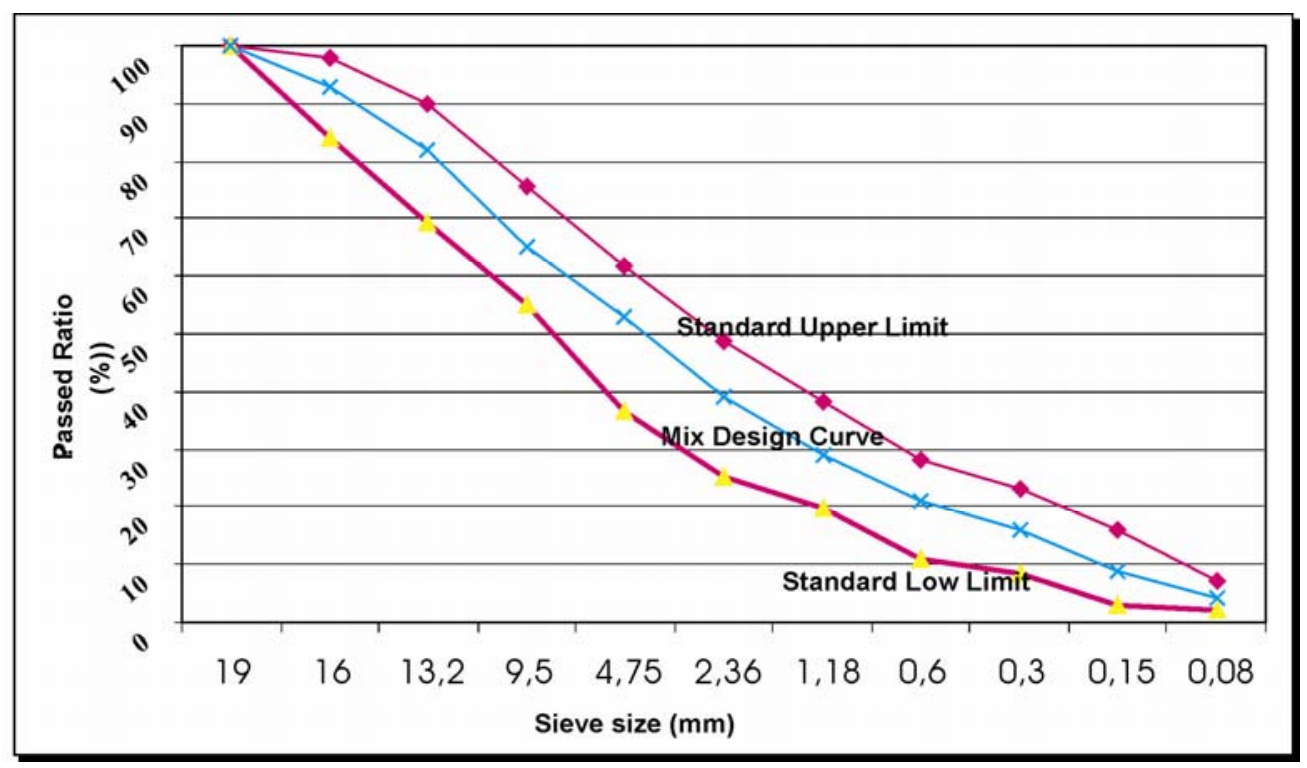

Fig 2. Data of aggregate (limestone and steel slag particles) sieve analysis

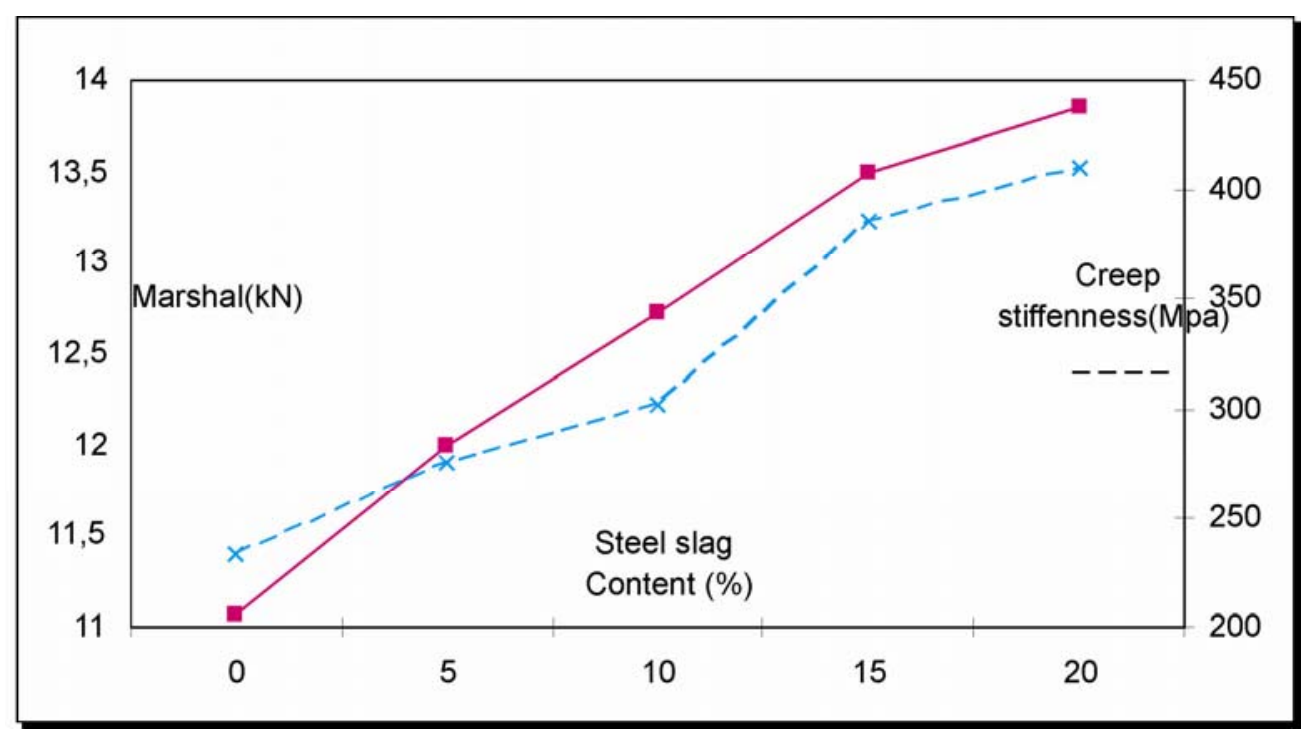

Fig 3. Marshall stability and creep stiffness as functions of different steel slag contents

1. Based on testing and analysing, steel slag can be used as asphalt mixture aggregate in expressway construction.

2. Waste broken steel slag can be used in asphalt concrete with the maximal size of $4,75 \mathrm{~mm}$ and optimal replacement ratio of $10 \%$.

3. The performances, such as strength index, high temperature stability and water stability, reach the standards.

4. The test has illustrated that the application of broken steel slag in asphalt mean useful treatments to improve the creep stiffness.

So this could be a new approach to treat and utilize the biggest solid waste, steel slag. The amount of wasted steel slag will decrease, and so will its impact on the environment. Besides, natural resources will be protected and saved if this way can be validated and applied availably in other areas.

\section{References}

1. MARTI, M. M. and MIELKE, P. E. A. Synthesis of asphalt recycling in Minnesota [R], Minnesota Local Road Research Board, Synthesis Report, 2002, p. 22-32.

2. LUXAN, M. P.; SOTOLONGO, R.; DORREGO, F.; HERRERO, E. Characteristics of the produced in the fusion of scrap steel by electric arc furnace. Cement and Concrete Research, 2000, 30, p. 517-519.

3. MOTZ, H.; GEISELER, J. Products of steel slag an opportunity to save natural resource. Waste Management, 2001, 21, p. 285-293.

4. SHAOPENG WU; YONGJIE XUE. Study on steel slag SMA. The 8th AATT International Conference. Paper collection, 2004, p. 456-460.

5. SHAOPENG WU; YONGJIE XUE. The application study of steel slag SMA-13 in WuhuangHighway Heavyrepairing Project. Journal of Wuhan University of Technology, 2003, Vol 25 (12), p. 113-115. 
6. KHABIRI, M. M. 1th Report of PH.D. Thesis "Development of a Mathematical Model for Increasing Flexible Pavement Life Cycle under Preventive Maintenance", Iran Science and Technology University, 2006.
7. Iran Road and Transplantation Ministry, Flexible Pavement Design Standard No 234, Tehran, 2001.

8. The Asphalt Handbook. Manual Series No 4 (MS-4), The Asphalt Institute, Lexington, KY, 1989.

\section{KELIO DANGOS PROFILAKTINIS REMONTAS IR MECHANINĖS PLIENO ŠLAKO ASFALTO SAVYBĖS}

\section{H. Ziari, M. M. Khabir}

\section{S antrauka}

Profilaktinis remontas yra naudingas, jei kelio dangos patvarumas didinamas išlaikant teikiamas paslaugas, kartu tai svarbi aplinkos problema. Plieno šlakas yra neorganinès kilmès ir negali būti nei deginamas, nei skaidomas, todèl sunkiai utilizuojamas. Šiame darbe stengtasi įvertinti asfalto betono charakteristika, kai dalis smulkios frakcijos yra pakeista susmulkintu plieno šlaku. Ši medžiaga trapi, joje daug anglies ir silikono, todėl vienas pagrindinių techninių plieno šlako rodiklių yra stiprumas. Tyrimams buvo naudotas AC 60-70 bitumas, klinčiu užpildas ir susmulkintas perdirbtas plieno šlakas. Maršalo tyrimas taikytas siekiant ịvertinti optimalų asfalto kiekị, asfalto betono tūrines savybes ir stiprumą esant skirtingai susmulkinto plieno šlako procentinei daliai. Tyrimo rezultatai parodė pakankamą plieno šlako asfalto betono stabilumą esant aukštai temperatūrai ir šlyties standumą. Tyrimo rezultatai parodè, kad plieno šlakas gali būti perdirbamas ir panaudojamas asfalto betone kaip sudètinè dalis.

Reikšminiai žodžiai: plieno šlakas, asfalto betonas, standumas šlyčiai, atliekos, profilaktinis remontas, perdirbimas.

\section{ПРОФИЛАКТИЧЕСКИЙ РЕМОНТ ДОРОЖНОГО ПОКРЫТИЯ И МЕХАНИЧЕСКИЕ СВОЙСТВА АСФАЛЬТА СО СТАЛЬНЫМ ШЛАКОМ}

\section{Г. Зиари, М. М. Кхабири}

Резюме

Профилактический ремонт полезен, если долговечность дорожного покрытия увеличивается при сохранении оказываемых услуг, а также в отношении охраны окружающей среды. Стальной шлак не является органическим веществом, поэтому его нельзя сжечь либо как-то утилизировать. Нами была предпринята попытка оценить характеристику асфальтобетона, мелкая фракция которого частично заменена дробленым стальным шлаком. Этот материал хрупок, в нем много угля и силикона, поэтому одним из основных технических показателей стального шлака является прочность. Исследованиям подвергался битум АС 60-70, известковый заполнитель и дробленый переработанный стальной шлак. Для определения оптимального количества асфальта, свойств и прочности асфальтобетона при разном процентном составе дробленого стального шлака применялся метод Маршалла. Исследования подтвердили достаточную стабильность асфальтобетона со стальным шлаком при высокой температуре, сдвиговую жесткость, а также возможность переработки стального шлака и применения его в качестве составной части асфальтобетона.

Ключевые слова: стальной шлак, асфальтобетон, сдвиговая жесткость, отходы, профилактический ремонт, переработка.

Ziari HASSAN. Assist Prof of Engineering (2001), College of Civil and Environmental Engineering, Science and Technology University of Iran.

Membership: member of Iranian Pavement Association; member of Editorial Board of Traffic Journal in Iran; member of Traffic Committee of Civil Engineering Association. Research interests: environmental management behavior of hot asphalt pavement, pavement mix design, concrete mix design, road engineering.

KHABIRI Mohammad Mahdi. PhD student (2003), Dept of Civil Engineering, Science and Technology University of Iran.

Lecturer of Civil Engineering at Vali-Asr Rafsanjan University. Membership: member of Iranian Pavement Association; member of Traffic Committee of Civil Engineering Association. Research interests: pavement preservation maintenance, hot mix asphalt, environmental management, pavement analytical design. 